\title{
The Comparison of Local Government Financial Health
}

\author{
Sri Rahayu* ${ }^{*} \quad$ Yudi Rahayu \\ Accounting Departement, Universitas Jambi, Kampus Pinang Masak Mendalo Indah, Muaro Jambi, Indonesia
}

\begin{abstract}
Measurement of the financial health of local governments is essential to assess the sustainability of services for the community. This study aims to compare the financial health of local governments using three approaches. The data used are BPK audited financial reports for Regency and City Governments in Jambi Province and data from BPS Jambi Province. The analytical tool used is a different test with Kruskal Wallis. The results showed that all hypotheses were proven, meaning that there were differences in the financial health condition of the district and city governments in Jambi Province for the three approaches used. Jambi City is the area with the healthiest financial situation for the FTMS model. Regencies and cities in Jambi Province with the Kloha model are in a healthy position. No region is in a place of fiscal emergency. All areas also do not face problems for the solvency-financial flexibility model. Overall, the financial condition of districts and cities in Jambi province is in a healthy financial situation. This research has implications for local governments in making monetary policies, especially related to optimizing asset management. In addition, the financial flexibility index is also fundamental to be considered by regions that have the potential for extraordinary events. Further researchers can develop other research methods such as qualitative and add research variables to obtain more complete results.
\end{abstract}

Keywords: Local Government Health, Revenue, Expenditure, Financial Report

DOI: $10.7176 /$ RJFA/12-14-07

Publication date:July $31^{\text {st }} 2021$

\section{Introduction}

The private sector's financial health research has been carried out, but it is still behind (Ritonga, 2016). Leaders need to continuously evaluate and monitor economic health conditions in their area of authority (Maher \& Nollenberger, 2009) because it involves the sustainability of public services. Local governments face shapes, the number of programs and activities that must carry out, and limitations. One of the limitations is financial problems. Therefore, local governments are required to have the ability to manage their finances effectively. But unfortunately, the apparatus still has limited ability to assess the health of local governments in a position to face problems or risks or health conditions (McDonald, 2018).

The government's financial health is unavoidably essential for the government to consider. It is fear that local government fiscal pressures will affect inter-governmental fiscal relations because of the necessity to help regions when an emergency is proven (Chung \& Williams, 2020). The public needs to be convinced that the government's finances are in a healthy condition. Local governments need legitimacy and support from all stakeholders. Legitimacy forms a general view (Gaus, 2011) to the government to be more accepted by the community (Rahayu, 2016). Therefore, the government needs to be positive and open to the public in conveying information about performance (Halim \& Kusufi, 2014) and financial health. The government needs the participation of the community. It will undoubtedly be easy to obtain if it has won the trust of the community.

Local governments often use strategies when facing financial difficulties, including efforts to reduce operational costs and increase regional income through local taxes (Elling, Krawczyk \& Carr, 2014). It, of course, can have an impact on the burden borne by the community. One way to achieve the financial health of local governments is by implementing an entrepreneurial pattern in service activities to the community. The government's entrepreneurial spirit is an effort to utilize resources to increase productivity and effectiveness. An important point that must consider, although implementing the principles of entrepreneurship but still not profitoriented, the main priority is still service to the community.

Government officials must be vigilant and act by prioritizing opportunities to do work and structures to achieve value for money (efficient, effective and, economical) (Sama, Ndunguru and, Mutahyoba, 2016). One of the performance indicators of government organizations assessed from the achievement of performance accountability. Every year, the Ministry of State Apparatus Empowerment and Bureaucratic Reform evaluates the accountability performance of government agencies. Every government agency is required to compile and report performance reports of government agencies based on Presidential Regulation Number 29 of 2014 concerning Performance Accountability System of Government Agencies, and Minister of State Apparatus Empowerment and Bureaucratic Reform Regulation Number 53 of 2014 concerning Technical Guidelines for Performance Agreements, Performance Reporting and Procedures Review of Government Agencies Performance Reports.

The progress of the 2017 Regency/City performance accountability achievements in Indonesia conveys by the MenPANRB in Jogyakarta on February 15, 2018. There are still 303 (63.80\%) Regencies/Cities that have 
received CC (50-60) and below. Government agencies that get an accountability score below 70 can potentially budget inefficiency (Inspectorate, 2016). The higher the achievement of the performance accountability value, the higher the level of budget efficiency (Rahayu, Yudi and, Rahayu, 2018). The achievement of the performance accountability predicate of local government agencies in Jambi Province also still needs improvement. In 2015, eight districts were still predicated as "CC" while the other three predicates as C. This predicate experienced an increase in 2017. Only four areas received the " $\mathrm{C}$ " predicate. After five consecutive years of getting the " CC " predicate, the performance of the Jambi Provincial Government has increased. For the evaluation of performance accountability in 2018, it managed to get the "B" predicate. There are five categories of predicate evaluation results for LAKIP: A, BB, B, CC, C, and D.

Research on the financial condition of local governments, especially in Indonesia, is still minimal (Ritonga, 2016). Research conducted by Ritonga (2012) researched the financial condition of district/city governments throughout Indonesia. The results showed that stakeholders were more concerned with the financial situation of local governments for the short-term horizon than the long term. Iqbal, Baga \& Dedi (2017) researched the financial health of district/city governments in West Java using Brown's measurement. The results show no significant difference in the health of the government's finances under study. This study examines differences in the financial condition of local governments using three perspectives (FTMS, Kloha and, Financial SolvabilityFlexibility). The difference between this research and the previous one is that the previous research usually only uses one approach to measure the financial condition of local governments. In addition, local governments effectively implemented this research conducted for financial statements after implementing the accrual basis.).

\section{Legitimacy Theory and New Public Management}

Legitimacy theory discusses views, perceptions, or assumptions about how an entity's action is appropriate and appropriate with values, beliefs, and social norms as defined together (Patrick, 2012). Government organizations do many things to gain trust from the point of view of the agent and principal relationship. The government needs legitimacy from the community. If the complete legitimacy stage has been obtained, the stakeholders have entirely accepted the organization to receive support for the actions (Rahayu, 2016). The organization needs legitimacy to maintain its survival. Legitimacy is an essential factor in the life of an organization (Meyer and Rowan, 1977).

The application of NPM to increase efficiency and effectiveness is a form of government action to gain legitimacy from the community. Although the NPM concept has received criticism from various parties because it is worried that government organizations will lose their non-profit spirit, they have moved to profit-seeking goals like private companies. Hood (1991) states that there are seven principles for implementing NPM, namely (1) Professional Management in the public sector; (2) Explicit standards and Measures of performance; (3) Greater emphasis on output controls; (4) Shift to disaggregation of units in the public sector; (5) Shift to greater competition in the public sector; (6) Stress on private-sector styles of management practice and (7) Stress on greater discipline and parsimony in resource use.

The seven principles above make the public sector more implementing organizational systems, contract mechanisms, transparency and accountability of performance, use of information technology, control using implementation and, adoption of market mechanisms (Mahmudi, 2016). The development of the NPM concept was followed by the abandonment of traditional budgets by public sector organizations and shifting to adopting performance-based budgeting (Yuwono et al., 2008).

\subsection{Regional Government Financial Health Assessment Model}

2.1.1 Model Fiscal Trend Monitoring System (FTMS).

FTMS is an early warning system to predict the financial condition of local governments. This model was developed by the international city/county management association (ICMA) in 1980 and was revised in 1994 and 2003. ICMA defines the financial condition of local governments as the ability of local governments to finance services in a sustainable manner (Ritonga, 2016). Some of the indicators often used include income indicators, expenditure indicators, operational position indicators, debt indicators, liability indicators, fixed asset indicators. The FTMS approach has the most ratio indicators compared to other ratios, namely forty-two indicators divided into financial and environmental hands. In this study, only ten financial ratios and six ratios for environmental indicators are calculated.

\subsubsection{Model Kloha.}

Local governments are considered to be experiencing financial difficulties if they do not meet standards in operations, debt, and community needs for several consecutive years. Some indicators that it can use include indicators for general funds, operational expenditures, the size of the available fund balance, and the current year's deficit. Kloha et al. (2005) used some indicators to assess the financial health of local governments. Its are population growth, actual tax value, general fund expenditure as a percentage of taxable value, general fund operating deficit, previous year general fund running a deficit, unrestricted fund balance size, fund deficit in the 
current or last year, and long-term debt. Of the nine ratios, only five ratios can use in this study: the population growth ratio, general fund operating deficit, general fund running deficit the previous year, available fund balance size, and fund deficit in the current year or the last year. Some information related to the actual tax value is not present in the financial statements, so it cannot process this study.

The use of ratios that connect the components in the financial statements to assess private companies' financial condition is widely used as a prediction of company bankruptcy (Altman, 1968). Such ratios have also been developed for local governments, such as the ten ratios offered by Brown (1993). The accrual basis by local governments refers to Government Regulation no. 71 of 2010 concerning Government Accounting Standards makes government financial reports more informative. The new financial reporting model allows regions to inform operating activities and financial position more comprehensively (Kioko, 2013). It can evaluate by using financial statement data.

2.2.3. Solvability and Flexibility Financial Model.

The six dimensions used to assess the financial condition of local governments refer to Ritonga (2016), namely

(1) The Short-Term Solvency Dimension Index consists of three indicators. It can use all indicators in this study.

(2) The Long-Term Solvency Dimension Index consists of three indicators. The three ratios: Ratio B and Ratio $\mathrm{C}$, are used as indicators. Ratio A is not used because the district and city governments in Jambi Province in 2013-2017 do not have long-term obligations. (3) The Budget Solvency Dimension Index consists of four indicators. The four ratios. It can use all indicators in this study. (4) The Financial Independence Dimension Index consists of two indicators. (5) Service Solvency Dimension Index consists of six indicators. It can use all indicators in this study. (6) The Financial Flexibility Dimension Index consists of four indicators. Indicator B and indicator $\mathrm{D}$ is used in this study. It cannot use all indicators because information on interest costs is not available in the observed local government financial reports. Ratio $\mathrm{C}$ cannot use because the district and city governments in Jambi Province in 2013-2017 do not all have long-term obligations.

Based on the description above, the researchers formulated three research hypotheses as follows:

H1: There are Differences in the Financial Health of District and City Governments in Jambi Province with the FTMS Approach

H2: There are Differences in the Financial Health of District and City Governments in Jambi Province with the Kloha Approach

H3: There are differences in the financial health of district and city governments in Jambi province with the financial solvency and flexibility Approach.

\section{Research Method}

We used the quantitative descriptive approach in this study. The researcher used Audited financial reports from district and city governments in Jambi Province in 2013-2017 and data from BPS. This study ignores the acquisition of audit opinion. The financial health condition that will assess is the five-year condition (20132017). Secondary data required comes from documents and policies that are relevant to the topic of study.

The analytical tool to determine the differences in financial conditions between district and city governments in Jambi Province carries out by conducting different tests for three approaches. The difference test is carried out by first knowing the normality of the data distribution for each model. Because the data are not distributed normally, a non-parametric comparison test is used. The number of data samples is more than two categories, with the number of each approach being different, so a further test analysis is used with Kruskal Walis.

Different tests were carried out in this study based on the ratio values obtained from the calculation of the indicator ratios of each local government. The average value of each aspect, factor, and indicator is used as the basis for making comparisons. In addition to conducting different tests, the researchers also analyzed financial health conditions between regions by ranking ratios.

The variable in this study is the local government's financial condition which is assessed from three models. Measurement of local government financial health refers to three models (Ritonga, 2016), namely:

a. Financial Solvency-Flexibility Model consisted of Short-Term Solvency, Long-Term Solvency, Service Solvency, Financial Independence, and Financial Flexibility.

b. The Fiscal Trend Monitoring System (FTMS) model consists of financial factors (indicators of income, expenditure, operating position, debt structure) and environmental factors. This model is an early warning system to predict the local government's financial condition.

c. The Kloha model is a model for detecting local government fiscal difficulties, where local governments cannot meet operating standards, debt, and community needs for several years in a row. Measurements using several indicators

\section{Result and Discussion}

The research team used a different test to see if there were differences in the financial conditions of districts and 
cities in Jambi Province from the three approaches. The initial stage carried out by the researcher was to test the normality of the data. The normality test of the data used the one-sample Kolmogorov-Smirnov Test. Testing the normality of the data for the three approaches, namely FTMS, Kloha, and financial solvency-flexibility, obtained data on the financial condition of districts and cities in Jambi Province in 2013-2017 that were not normally distributed. Therefore, the research team used the Kruskal Wallis Test to compare financial conditions. In addition to the abnormal distribution of data, the Kruskal Wallis test chose because the number of independent samples used was more than two from different populations. The results of the comparison of financial conditions for the three models are described as follows.

\subsection{The Difference between Financial Health With FTMS Model}

The comparative Test of financial conditions using the FTMS approach for districts and cities in Jambi Province in 2013-2017 obtained the asymp significance value or P-value of 0.000 below 0.000 . The first hypothesis of this study is proven. There are differences in the financial conditions of districts and cities in Jambi Province in 2013-2017 for seventeen indicators of the FTMS approach.

After statistically proving the difference in financial conditions with the FTMS approach, the research team then analyzed to determine which areas between districts and cities in Jambi Province had the healthiest states. The way to do this is first by ranking the best (position 1) and less good (position 11) financial conditions. The research team ranked the average value of each indicator from the best and so on for all hands. Of the twentyfour FTMS indicators, the research team could only use seventeen hands because some data were not available in local government financial reports. The seventeen indicators are divide into eleven indicators for economic factors and six indicators for environmental factors. The order of the seventeen indicators of the FTMS approach can see in Table 1.

Table 1. District and Municipal Financial Health Ranking -FTMS Model

\begin{tabular}{|c|c|c|c|c|c|c|c|c|c|c|c|c|c|c|c|c|c|}
\hline \multirow{3}{*}{$\begin{array}{l}\text { Local } \\
\text { Government }\end{array}$} & \multicolumn{11}{|c|}{ Financial } & \multirow{2}{*}{\multicolumn{6}{|c|}{$\begin{array}{c}\text { Environment } \\
\text { Resources }\end{array}$}} \\
\hline & \multicolumn{4}{|c|}{ Income } & \multicolumn{2}{|c|}{$\begin{array}{c}\text { Expend } \\
\text { iture }\end{array}$} & \multicolumn{3}{|c|}{ Operational } & \multirow{2}{*}{$\begin{array}{r}\begin{array}{c}\text { Liabil } \\
\text { ities }\end{array} \\
10 \\
\end{array}$} & \multirow{2}{*}{$\begin{array}{r}\begin{array}{r}\text { Fixed } \\
\text { Asset }\end{array} \\
11 \\
\end{array}$} & & & & & & \\
\hline & 1 & 2 & 3 & 4 & 5 & 6 & 7 & 8 & 7 & & & 12 & 13 & 14 & 15 & 16 & 17 \\
\hline Kota Jambi & 1 & 1 & 1 & 3 & 3 & 11 & 10 & 1 & 3 & 1 & 8 & 1 & 1 & 2 & 11 & 11 & 9 \\
\hline Muaro Jambi & 10 & 5 & 3 & 8 & 1 & 10 & 9 & 5 & 10 & 7 & 3 & 2 & 3 & 11 & 10 & 10 & 10 \\
\hline Kerinci & 3 & 7 & 2 & 5 & 8 & 7 & 7 & 9 & 9 & 8 & 9 & 9 & 5 & 8 & 7 & 7 & 7 \\
\hline Sungai Penuh & 2 & 10 & 7 & 9 & 11 & 9 & 2 & 11 & 7 & 4 & 5 & 11 & 2 & 4 & 2 & 9 & 1 \\
\hline Batanghari & 5 & 4 & 9 & 10 & 9 & 1 & 8 & 6 & 8 & 2 & 10 & 8 & 10 & 7 & 6 & 1 & 6 \\
\hline Bungo & 4 & 3 & 5 & 2 & 7 & 4 & 11 & 4 & 5 & 9 & 11 & 4 & 4 & 3 & 8 & 4 & 3 \\
\hline Tebo & 11 & 8 & 8 & 1 & 2 & 8 & 5 & 10 & 11 & 10 & 4 & 5 & 7 & 5 & 3 & 8 & 4 \\
\hline Merangin & 9 & 9 & 6 & 4 & 6 & 5 & 6 & 2 & 4 & 5 & 7 & 3 & 8 & 6 & 9 & 5 & 11 \\
\hline Sarolangun & 6 & 6 & 4 & 6 & 4 & 6 & 3 & 7 & 1 & 6 & 6 & 7 & 9 & 1 & 5 & 6 & 5 \\
\hline Tanjabbar & 7 & 2 & 10 & 11 & 5 & 3 & 1 & 3 & 6 & 11 & 1 & 6 & 6 & 9 & 4 & 3 & 2 \\
\hline Tanjabtim & 8 & 11 & 11 & 7 & 10 & 2 & 4 & 8 & 2 & 3 & 2 & 10 & 11 & 10 & 1 & 2 & 8 \\
\hline
\end{tabular}

\section{Source: data processed by researchers}

Next, the team analyzed the trend of each ratio to determine the local government's financial condition by the FTMS model. Researchers look at the movement of ratio data for five years of observation, whether it shows an unwanted trend. The trend's consideration is based on the direction of the move from the ratio calculations carried out.

FTMS does not assign a score for each trend, only the direction of the unwanted movement. The researcher modified Brown (1993). The next researcher made a score for the direction of the trend based on an analysis of the ratio. Researchers divide four categories as follows:

a. Score 1 for "early warning" if the trend obtained is not desirable

b. Score 0.5 for "moderate potential for the early warning" if the ratio fluctuates and tends to follow an undesirable trend.

c. Score 0.25 for "moderate potential for the early warning" if the ratio fluctuates and tends to be against an unwanted trend.

d. Score 0 for "healthy" if the trend obtained is opposite to the unwanted one.

Direction unwanted movement described sum- scores order seventeen indicators, Its can seen table 2. 
Table 2. Results of Assessment Scores for the Trends in the FTMS Approach in Jambi Province Regency and City in 2013-2017

\begin{tabular}{|l|c|}
\hline Local Government & Trend Score Early Warning \\
\hline Kota Jambi & 3.75 \\
\hline Kerinci & 5.00 \\
\hline Sarolangun & 5.00 \\
\hline Muaro Jambi & 5.75 \\
\hline Batanghari & 6.50 \\
\hline Tanjabbar & 6.50 \\
\hline Merangin & 7.00 \\
\hline Sungai Penuh & 7.25 \\
\hline Tebo & 7.25 \\
\hline Tanjabtim & 7.50 \\
\hline Bungo & 7,75 \\
\hline
\end{tabular}

Source: data processed by researchers

The scoring score for the highest unwanted trend area is 17 points, and vice versa for the opposite trend, the position is 0 . Based on this, it can be seen that overall, no area reaches the unwanted trend position for early warning up to $50 \%$ of optimal (8.5).

Jambi City is the area with the healthiest financial condition for the FTMS approach, with a score of 3.75. Meanwhile, the financial condition with the highest early warning score for Jambi Province is Bungo Regency. Although the results of this scoring are only based on an analysis of the quantitative data presented in the financial statements, they can be used as an early warning indication for local governments.

Jambi City is the city with the healthiest financial condition, with a healthy position for eight indicators: per capita, income surplus, operational surplus, capital expenditure, population density, per capita expenditure, and capital expenditure. Jambi City is the area that has the largest population but is still able to be the only area for per capita population that is categorized as healthy. The trade and service sectors are the mainstays of the highest income for the local government and the people of Jambi City. With a large population, primarily immigrants from outside the region, Jambi City has one indicator that falls into the "early warning" category, namely the unemployment rate. From the environmental aspect, Jambi City is also one of the areas that have high disaster potential in Jambi Province. The types of disasters that often occur include floods, strong winds, and cyclones, and are affected by the impact of smoke haze from land and forest fires from other areas.

Muaro Bungo Regency, which is in the lowest position in terms of health, faces four indicators that fall into the early warning category, namely income per capita, fixed expenditure, operational deficit, and mandatory expenditure. Local governments are also starting to point to the potential for low early warning for five indicators and medium early warning for three indicators. Bungo Regency is still in a healthy condition for indicators of working capital, liquidity, short-term debt, population density, and per capita expenditure.

\subsection{Differences in Financial Health with the Kloha Model}

The results of the Kruskal Wallis test for comparison of financial conditions using the Kloha model with five indicators for regencies and cities in Jambi Province in 2013-2017 show a significant asymp value or P-value of 0.000 , which is below 0.05 . The second hypothesis of this study is proven. There are differences in the financial conditions of districts and cities in Jambi Province in 2013-2017 for the five indicators of the Kloha approach.

After statistically proving the difference in financial conditions with Brown's approach, the research team then conducted an analysis to determine which areas between districts and cities in Jambi Province had the healthiest conditions. The way to do this is to rank the best (position 1) and less good (position 11) financial conditions. The order of 1 to 11 by the research team ranked the average value of each indicator from the best and so on for all indicators. Of all the kloha indicators, the research team could only use five indicators because there were some data that could not be obtained from the District and City Financial Reports. The order of the values of the nine indicators of the Kloha model can be seen in table 3 
Table 3. District and City Financial Health Ranking Kloha Model

\begin{tabular}{|l|c|c|c|c|c|}
\hline Local Government & $\mathbf{1}$ & $\mathbf{2}$ & $\mathbf{3}$ & $\mathbf{4}$ & $\mathbf{5}$ \\
\hline Kota Jambi & 7 & 11 & 1 & 4 & 10 \\
\hline Muaro Jambi & 1 & 2 & 4 & 11 & 2 \\
\hline Kerinci & 11 & 7 & 2 & 6 & 6 \\
\hline Sungai Penuh & 9 & 1 & 10 & 2 & 8 \\
\hline Batanghari & 8 & 8 & 9 & 10 & 1 \\
\hline Bungo & 2 & 10 & 7 & 9 & 3 \\
\hline Tebo & 5 & 4 & 8 & 7 & 4 \\
\hline Merangin & 6 & 9 & 3 & 8 & 5 \\
\hline Sarolangun & 3 & 6 & 5 & 3 & 9 \\
\hline Tanjabbar & 4 & 3 & 6 & 1 & 11 \\
\hline Tanjabtim & 10 & 5 & 11 & 5 & 7 \\
\hline
\end{tabular}

Source: data processed by researchers

From table 3, it can be seen that although statistically, it is proved that there are differences between regions, there is no single region that is dominant in a specific position for its financial condition. For example, for the first rank for five indicators spread over five districts and cities, namely Muaro Jambi Regency for indicator 1, Sungai Penuh City for indicator 2, Jambi City for indicator 3, Tanjung Jabung Barat Regency for indicator 4, and Batang Hari Regency for indicator 5.

The average population growth development (indicator 1) of districts and cities in Jambi Province from 2012 to 2017 was $1.62 \%$. The area that experienced the highest increase was Muaro Jambi Regency and followed by Bungo Regency. Kerinci Regency is the area with the lowest population growth. The parent area of the expansion of Sungai Penuh City only experienced an average population growth of $0.40 \%, 0.65 \%$ lower than the area resulting from its development. Kerinci Regency is considered quite effective in carrying out this movement from the point of view of population control.

From a financial point of view, population growth can view as a burden to local governments. Local governments with high population growth will increase public service spending, which is also higher than regions with low population growth. But on the other side, a high population can also be potential if the area can manage it properly. A productive and creative population will be one of the regional development resources that has an impact, one of which is the contribution of regional income. The higher the population growth rate (within reasonable limits), it will support the healthy potential of an area.

In the second indicator, namely the general fund operational deficit ratio, during 2013-2017, no one had the potential for problems in financial conditions. Full River City ranks at the top for this indicator. In the third indicator, the focus is that general funds used for regional government operational activities should not experience a deficit because it will disrupt service activities provided to the community and disrupt the smooth running of internal activities of government organizations. Therefore, Kloha et al. (2005) make the occurrence of a deficit an indicator of the potential for financial difficulties. On the other hand, a government that can maintain a surplus level will invest through financing patterns to increase local revenue sources. Four regions that only experienced one year of deficit. Jambi City is the healthiest area for this third indicator.

Kloha et al. (2005) stated that local governments are considered indications of potential regional financial problems if the standard deviation of the available fund balance ratio is $<0.13$. Tanjung Jabung Barat Regency is the only region with a general fund balance ratio above 0.13 , so it can be said to have the healthiest position for this indicator. For the fifth indicator, all districts and cities in Jambi Province do not indicate potential financial problems seen from this indicator. Because We found no area to have a SILPA deficit problem, a high SILPA can be used for financing. For example, short-term investments can generate additional income for the region. In addition, it can also be invested in the long term so that it will obtain extra fixed income periodically for the area. Although some views also state that a Silpa that is too high also cannot be considered too good, it can raise several possibilities, namely, the non-implementation of programs and activities that have been previously planned. Silpa is good if it is obtained from the efficiency of funding activities that have been carried out well and the output of activities has been achieved. In addition, SILPA can also come from the amount of realized income that is higher than the budget that has been set.

The research team then determined the expected value of each ratio to determine the financial condition of the local government, referring to Kloha et al. (2005). The determination of the standard value is carried out according to the type of ratio that is calculated. The sum of the scores of each ratio, the overall maximum score is 10 points. The categorization is if the local government gets $0-4$ points, it is categorized as fiscally healthy, a 
score of 5 points is categorized as fiscal alert, and a 6-7 is a fiscal warning. A total score of 810 points is a fiscal emergency. Because only five indicators with a maximum value of 5 points were used in this study, we could not use ten indicators. Therefore, the research team made adjustments to assess the health condition of the local government, namely if it gets 5 points, it means a fiscal warning, 0-3 points is healthy, and four fiscal caution points. This study does not use the category of fiscal emergency because the total results of the calculation of the ratio assessment will not reach 8 points. The results of the evaluation are presented in Table 4.

Table 4. Results of District and City Value Standards -Kloha Model

\begin{tabular}{|l|c|}
\hline Local Government & Total Points \\
\hline Kota Jambi & 2 \\
\hline Muaro Jambi & 3 \\
\hline Kerinci & 2 \\
\hline Sungai Penuh & 3 \\
\hline Batanghari & 3 \\
\hline Bungo & 3 \\
\hline Tebo & 3 \\
\hline Merangin & 2 \\
\hline Sarolangun & 2 \\
\hline Tanjabbar & 2 \\
\hline Tanjabtim & 3 \\
\hline
\end{tabular}

\section{Source: data processed by researchers}

Based on Table 4, it can see that all regencies and cities in Jambi Province for the year 2013-2017 are in a healthy position because the expected results of the assessment are in the 0-3 range. Five regions get a score of 2 and six areas with a score of 3 . Not a single place gets a score of up to 4 .

4.2 The Difference between Financial Health and Financial Solvency-Flexibility Approach The financial health comparison test results using the financial solvency-flexibility approach for districts and cities in Jambi Province in 2013-2017 obtained a significant asymp value or P-value of 0.004 below 0.05 . Hypothesis 3 proves that there are differences in the financial conditions of districts and cities in Jambi Province in 2013-2017 for the six indicators of the solvency-flexibility approach.

Although it is proven that there are statistical differences, there is no accumulation of the healthiest or least favorable financial conditions in an area, as presented in Table 5.

Table 5. Financial Health Ranking-Financial Solvency-Flexibility Model

\begin{tabular}{|l|c|c|c|c|c|c|}
\hline Local Government & $\mathbf{1}$ & $\mathbf{2}$ & $\mathbf{3}$ & $\mathbf{4}$ & $\mathbf{5}$ & $\mathbf{6}$ \\
\hline Kota Jambi & 9 & 9 & 11 & 1 & 11 & 11 \\
\hline Muaro Jambi & 5 & 4 & 3 & 9 & 9 & 2 \\
\hline Kerinci & 10 & 11 & 6 & 4 & 6 & 10 \\
\hline Sungai Penuh & 4 & 5 & 8 & 10 & 1 & 3 \\
\hline Batanghari & 11 & 10 & 9 & 5 & 4 & 7 \\
\hline Bungo & 8 & 7 & 10 & 2 & 10 & 8 \\
\hline Tebo & 6 & 8 & 5 & 7 & 7 & 9 \\
\hline Merangin & 7 & 6 & 7 & 8 & 8 & 6 \\
\hline Sarolangun & 3 & 3 & 2 & 3 & 5 & 4 \\
\hline Tanjabbar & 2 & 2 & 1 & 6 & 3 & 5 \\
\hline Tanjabtim & 1 & 1 & 4 & 11 & 2 & 1 \\
\hline
\end{tabular}

Source: data processed by researchers

The difference in financial condition with this approach can be seen from the distribution of the best (position 1) and poor (position 11) financial condition ranking conditions.

Jambi City is perfect for indicators of financial independence because the level of original regional income is higher than other regions, although the amount of regional expenditure is also high. East Tanjung Jabung Regency is good for indicators of short-term solvency, long-term solvency, and financial flexibility because the value of short-term debt is lower than other regions. Service Solvency Indicators the highest average score was obtained by Tanjung Jabung Barat Regency. Sungai Penuh City has the best financial condition for service solvency indicators because the population is much lower than in other areas.

The short-term solvency of districts and cities in Jambi Province shows a high number. This high ratio not 
only reflects the still low level of current liabilities in the year of observation. This ratio also reflects the overestimation of existing assets, particularly cash and cash equivalents and their receivables. Local governments have the potential to optimize current asset management, significantly cash, so that they can improve services to the community and increase regional income, for example, through short-term investments.

Financial conditions that reflect the ability of local governments to provide and maintain the quality of public services needed and desired by the community are reflected in this index (Ritonga, 2016). Local governments can carry out their duties if supported by sound fiscal conditions and good financial management (Iqbal, Baga \& Hakim, 2017).

The solvency of services is measured by using indicators seen from total assets, total equity, total fixed assets, total spending, total public spending, and total capital expenditure compared to the total population. One of the factors that greatly affect this ratio is the population. External factors need to consider in assessing regional financial conditions (Suryani and Faisal, 2016).

Sungai Penuh City, with a five-year index average of 0.96 , is the local government with the highest service index. They were then followed by East Tanjung Jabung Regency with an average index of 0.54 . The local government with the lowest average service solvency index is Jambi City. Jambi City gets an average of total assets, fixed assets, and others much higher than Sungai Penuh City. Still, the population of Jambi City is far above the total population of Sungai Penuh City. In 2017 the population of each region was Jambi City, as many as 583,487 people, while Sungai Penuh City was only 87,971 (BPS, 2018). This means that the service burden that the City of Jambi must provide is much higher than that of the City of Sungai Penuh.

Financial flexibility shows the financial condition of local governments that are increasingly ready to face extraordinary events from internal or external (Ritonga, 2016). District and city governments in Jambi province are still classified as regions ready to face potential extraordinary events. Tanjung Jabung Timur Regency is the area with the highest average index, while Jambi City has the lowest index average in the five years. District and City Governments in Jambi Province must pay attention to the level of financial flexibility ratios because they include areas with the potential for extraordinary external events. Jambi Province has the potential for disasters, including floods and forest fires that impact smoke pollution (Fitria \& Syamsir, 2019) and landslides in several western districts.

Overall, district and city governments in Jambi province are categorized as in sound financial condition. To improve services for the community, the government may consider increasing cooperation between regions. The use of cooperation can be one of the implementations of new public management (Warner, Aldag \& Kim, 2020). Aldag \& Warner (2018) and Zeemering (2019) prove that inter-regional cooperation can lead to lower costs, quality of service, and better coordination of services across regions. It can also help ensure that broader public goals are met (Warner, Aldag \& Kim, 2020). The government must be creative to avoid getting caught in financial difficulties (Overmans \& Noordegraaf, 2014). Local governments must be able to increase creativity in the management and development of potential regional resources. Lhutfi, Ritchi \& Yudianto (2020) and Muda (2012) prove that increasing the ability of regions to earn their income can reduce fiscal stress.

\section{Result and Discussion}

Based on the results and discussion of this study, it can conclude that there are differences in the financial health condition of the district and city governments in Jambi Province for the three approaches used. Jambi City is the area with the healthiest financial situation for the FTMS approach. Meanwhile, the financial condition with the highest early warning score for Jambi Province is Bungo Regency. Regencies/cities Jambi Province get the healthy position with Kloha model. No region is in a place of fiscal emergency.

Regions categorized as healthy for the financial solvency-flexibility approach are also spread out, not piling up in one area. Jambi City is perfect for indicators of financial independence because the level of original regional income is higher than other regions. East Tanjung Jabung Regency is good for indicators of short-term solvency, long-term solvency, and financial flexibility because the value of short-term debt is lower than other regions. Service Solvency Indicators the highest average score was obtained by Tanjung Jabung Barat Regency. Sungai Penuh City has the best financial condition for service solvency indicators because the population is much lower than in other areas.

This research has implications for local governments in making financial policies. They should pay attention to short-term solvency ratios that are too high because the impact is that current assets are not optimally used for services to the community. Another index that must consider is the service solvency index, which can measure the quantity and quality of services to the community. In addition, the financial flexibility index is also fundamental to be considered by regions that have the potential for extraordinary events. The limitations of this study include only using secondary data to assess the financial health condition of local governments. Further researchers can develop other research methods such as qualitative and add research variables to obtain more comprehensive results. 
References

Aldag, A. M., \& Warner, M.E. (2018), "Cooperation, Not Cost Savings: Explaining Duration of Shared Service Agreements." Local Government Studies 44 (3): 350-370.

Altman, E. I. (1968), "Financial Ratios, Discriminant Analysis and the Prediction of Corporate Bankruptcy", Journal of Finance 23, 589-609.

Basri, H., \& Nabiha, S. (2014), "Accountability Of Local Government: The Case Of Aceh Province, Indonesia", Asia Pacific Journal of Accounting and Finance 3 (Dec)(1).

BPS, 2018, Jambi dalam Angka 2018, https://jambi.bps.go.id/publication/2018/08/16/463fb7693 f6a21782bbe309c/ provinsi-jambi-dalam-angka-2018.html.

Brown, K. W. (1993), "The 10-Point Test of Financial Condition: Toward an Easy-to-Use Assessment Tool for Smaller Cities", Government Finance Review 21(December), 21-25.

Chung, I, W \& Williams, D. (2020), "Local governments' responses to the fiscal stress label: the case of New York", Local Government Studies, DOI: 10.1080/03003930.2020.1797693.

Elling, R., Krawczyk, K \& Carr, J. (2014), "What Should We Do? Public Attitudes about How Local Government Officials Should Confront Fiscal Stress", Local Government Studies 40:3, 380-402.

Fitria, F., \& Syamsir, S. (2020), "Sanksi Administrasi Terhadap Kebakaran Hutan Dan Lahan Oleh Badan Hukum Perdata Di Kabupaten Muaro Jambi”, Jurnal Sains Sosio Humaniora 4(2), 479-494.

Gaus, D. (2011), "The Dynamics of Legitimation, Why the Study of Political Legitimacy Need More Realism", Woriking Paper. Centre for European Studies. University of Osio. Osio. Retrieved from http://www.arena.uio.no, 2011.

Halim, A., \& Kusufi, M. S. (2014), “Teori, Konsep, dan Aplikasi Akuntansi Sektor Publik dari Anggaran hingga Laporan Keuangan, dari Pemerintah hingga Tempat Ibadah", Jakarta: Salemba 4.

Hood, C. (1991), "A New Public Management for All a Season", Public Administration 69(Spring), 3-19.

Iqbal. M., Baga. L.M \& Hakim, D.B. (2017), "Desain Formulasi Penilaian Kinerja Kesehatan Fiskal dan Pengelolaan Keuangan Daerah (Studi Kasus Provinsi Jawa Barat)", Jurnal BPPK 10, Nomor 1, 11-23.

Kioko, S. N. (2013), "Reporting on the Financial Condition of the States: 2002-2010", Journal of Public Budgeting, Accounting \& Financial Management 25(1), 165-198.

Kloha, P., Weissert, C. S., \& Kleine, R. (2005), "Developing and Testing a Composite Model to Predict Local Fiscal Distress", Public Administration Review 65(3), 313-323.

Lawrence, S. (2001), "Persistence of Web References in Scientific Research", Computer 34, 26-31.

Lhutfi, I, Rtichi, H \& Yudianto, I (2020), "Do the Growth of Original Local Government Revenues and The Growth of Capital Expenditure Affect Fiscal Stress?", Journal of Economics, Business and Accountancy Ventura, Volume 23, No. 1, April-July, 2020, Pages 1-11.

Maher, C. S., \& Nollenberger, K. (2009). "Revisiting Kenneth Brown's 10-Point Test", Government Finance Review October, 61-66

Mahmudi. (2016), “Akuntansi Sektor Publik”, Cetakan Pertama, UII Press, Yogyakarta.

McDonald, B. D. (2018), "Local Government and The Issue of Fiscal Health", State and Local Government Review 5(1), 46-55.

Meyer, J. W., dan Rowan, B. (1977), "Institutionalized Organization Formal Structure as Myth and Ceremony", American Journal of Sociology 83(No. 2 (Sep)), 340-363.

Muda, I. (2012), "Variabel yang mempengarhui Fiscal Stress pada Kabupaten/Kota Sumatera Utara", Jurnal Keuangan \& Bisnis Volume 4, No 1, Maret, 27-46.

Overmans, J. F. A., \& Noordegraaf, M. (2014), "Managing Austerity: Rhetorical and Real Responses to Fiscal Stress in Local Government" Public Money \& Management 34:2, 99-106.

Patrick. H. (2012), "Legitimacy in Institutional Theory: Three Essays on Social Judgments in A Globalized World", Dissertation. Posted at the Zurich Open Repository and Archive, University of Zurich, ZORA URL: https://doi.org/10.5167/uzh-72272.

Rahayu, S, (2016), "Institutionalization Process of SOA Funds Budgeting at Basic Education Institutions in Indonesia", Research Journal of Finance Accounting 7(4)

Rahayu. S., Yudi \& Rahayu. (2018), "Shifting In The Role Of The Government Internal Auditors, How To Achive It?", International Conference Economics, Bussiness and Management, Bali, November 2018.

Ritonga, I. T. (2016), “Analisis Laporan Keuangan Pemerintah Daerah”. Yogyakarta: UGM Press

Ritonga, I. T., Clark, C., \& Wickremasinghe, G. (2012), "Assessing Financial Condition of Local Government in Indonesia: An Exploration", Public Municipal Finance 1(2), 37-50.

Sama, H. K., Ndunguru, P. C., \& Baisi, M. D. (2014), "Entrepreneurial Government: Causal Relationship between Transaction Costs and Value for Money", International Journal of Managerial Studies and Research 2(9), October, 63-74.

Suryani dan Basri, 2016, Analisis Kondisi Keuangan Daerah Kabupaten/Kota Di Aceh Dan Di Sumatera Utara, Jurnal Bisnis dan Ekonomi (JBE), Vol. 23Maret 2016, 63-71, No.1 63 
Tama, A. I. (2015), “Analisis Kinerja Keuangan Pemerintah Daerah melalui Analisis Rasio Keuangan APBD Kabupaten/Kota di Indonesia Sebelum dan Sesudah Penerapan Undang-undang Nomor 28 Tahun 2009”. Jurnal Riset Akuntansi dan Komputerisasi Akuntansi, 6(2), 20-32.

Warner M.E, Aldag A.M \& Kim, Y. (2020), "Privatization and Inter-municipal Cooperation in US Local Government Services: Balancing Fiscal Stress, Need and Political Interests", Public Management Review, DOI: $10.1080 / 14719037.2020 .1751255$

Yuwono, S., Utomo, D. C., Zein, S., \& Azrafiany. (2008), APBD dan Permasalahannya (Panduan Pengelolaan Keuangan Daerah)", Malang, Bayu Media.

Zelmiyanti, R. (2016), "Pendekatan Teori Keagenan pada Kinerja Keuangan Daerah dan Belanja Modal (Studi pada Provinsi di Indonesia)", Jurnal Riset Akuntansi dan Komputerisasi Akuntansi, 7(1), 11-21.

Zeemering, E. S. (2019), "Do Interlocal Contracts Seek Collaborative Efficiency? An Investigation of Police Service Delivery in California Cities", Public Management Review, 21(7): 968-987. 